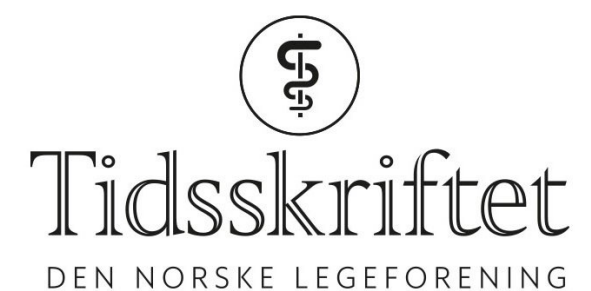

DEN NORSKE LEGEFORENING

\title{
Omega-3-tilskudd og hjerte- og karsykdommer
}

KOMMENTAR

\section{DAG TVEITEN}

E-post: dt@lab1.no

Dag Tveiten er bioingeniør og laboratoriesjef ved Lab1.

\section{JON NORSETH}

\section{CLEMENS VON SCHACKY}

Forfatterne har oppgitt følgende interessekonflikter: Interessekonflikt: Dag Tveiten og Jon Norseth er ansatt i Lab1 medisinske laboratorium, Clemens von Schacky er leder av Omegametrix, et laboratorium for fettsyreanalyser og mottar honorarer for presentasjoner og konsulentvirksomhet for BASF/Pronova, EPAX og Norsan.

Vi tillater oss å komme med noen kommentarer til artikkel av Myhre et al. om effekt av omega-3 fettsyrer (1). Omega-3 fettsyrer kan ikke evalueres ved hjelp av tradisjonelle randomiserte kontrollerte intervensjonsfors $\emptyset \mathrm{k}$. Alle mennesker har et minimumsnivå av omega-3-fettsyrer i kroppen $(2,3,4)$. Dette nivået blir vanligvis estimert som en prosentandel av EPA og DHA i røde blodlegemer, fortrinnsvis ved bruk av en standardisert og veldokumentert analysemetode (HS-Omega-3 Index®) $(2,3,4)$.

Så langt har kliniske data fra epidemiologiske studier eller intervensjonsfors $ø \mathrm{k}$ og nivået av omega-3-fettsyrer korrelert godt, men kun når man hensyntar utgangsnivået av omega-3fettsyrer i blodet $(4,5)$. Man kan ikke se bort fra baseline nivåer og bruke ensartede og faste doser, som i en medikamentstudie. Den nylig publiserte Cochrane metaanalysen som vurderte omega-3-fettsyrer som medikament, fant likevel en signifikant reduksjon av kardiovaskulær dødelighet (8\%), koronar hjertesykdomsdødelighet (10\%) og koronare hjertesykdomshendelser (9\%) med marine omega-3-fettsyrer (6). Resultatet ble svekket på bakgrunn av inklusjon av mange nøytrale studieresultater, slik som ASCEND-studien, som rekrutterte deltakere med en Omega-3-Indeks ved baseline nesten innenfor målområdet, og etterlot derfor ikke store rom for bedring.

I REDUCE-It studiet sammenlignet man effekten av legemiddelet etyl-EPA med placebo, samt etyl-EPA med placebo justert for omega-3 nivået i blodet: Sammenligning av etyl-EPA med placebo viste $25 \%$ reduksjon på primære endepunkt, total dødelighet med $13 \%$, kardiovaskulær dødelighet med $20 \%$, hjerneslag med $28 \%$ og dødelig eller ikke-dødelig hjerteinfarkt med $31 \%$. Til sammenligning, når effekten ble evaluert ut fra oppnådd nivå av omega-3 i blod, oppnådde primære endepunkt $75 \%$ reduksjon, total dødelighet med $40 \%$, kardiovaskulær dødelighet med $40 \%$, hjerneslag med $50 \%$ og dødelig eller ikke-fatalt 
hjerteinfarkt med $55 \%$ reduksjon.

Det er etter vår mening meningsløst å undersøke effekten av tilskudd med marine Omega-3 fettsyrer i prospektive randomiserte placebokontrollerte studier uten å korrelere med Omega-3 fettsyre nivået i blod.

LITTERATUR:

1. Myhre PL, Seljeflot I, Arnesen H. Omega-z-tilskudd forebygger ikke hjertesykdom. Tidsskr Nor Legeforen 2021; 141. doi: 10.4045/tidsskr.21.0033. [PubMed][CrossRef]

2. von Schacky C. Omega-3 fatty acids in cardiovascular disease-an uphill battle. Prostaglandins Leukot Essent Fatty Acids 2015; 92: 41-7. [PubMed][CrossRef]

3. Rice HB, Bernasconi A, Maki KC et al. Conducting omega-3 clinical trials with cardiovascular outcomes: Proceedings of a workshop held at ISSFAL 2014. Prostaglandins Leukot Essent Fatty Acids 2016; 107:30-42. [PubMed][CrossRef]

4. von Schacky C. Confusion about the effects of omega-3 fatty acids : Contemplation of study data taking the omega-3 index into consideration. Internist (Berl) 2019; 60: 1319-27. [PubMed][CrossRef]

5. von Schacky C. Importance of EPA and DHA blood levels in brain structure and function. Nutrients 2021; 13: 1074. [PubMed][CrossRef]

6. Abdelhamid AS, Brown TJ, Brainard JS et al. Omega-3 fatty acids for the primary and secondary prevention of cardiovascular disease. Cochrane Database Syst Rev 2020; 3: CDoo3177.

[PubMed][CrossRef]

Publisert: 28. juni 2021. Tidsskr Nor Legeforen. DOI: 10.4045/tidsskr.21.0466

(C) Tidsskrift for Den norske legeforening 2020. Lastet ned fra tidsskriftet.no 